\title{
BNWL-174
}

$58-$

\section{UNDERWATER REFURBISHING OF FUEL ELEMENTS}

DEVELOPMENT

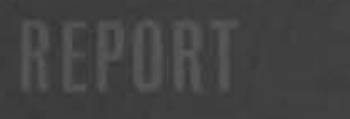
C. H. ALLEN and

R. E. SHARP

DECEMBER， 1965

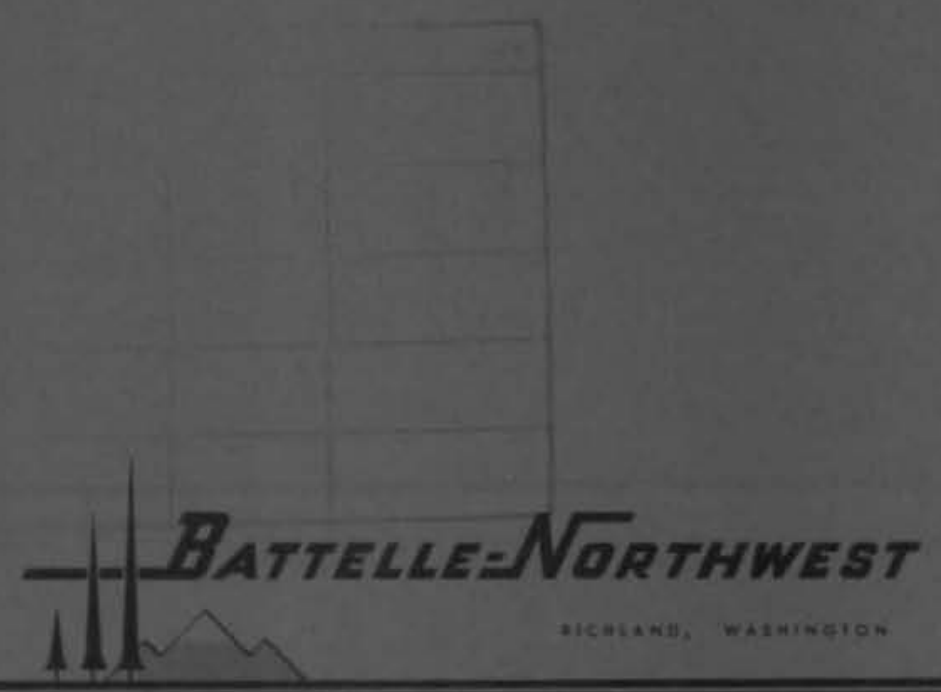

PACIFIC NORTHWEST LABORATORY operated bY BATTELLE MEMORLAL INSTITUTE 


\title{
LEGAL NOTICE
}

This repert was prepared as an account of Government sponsored work. Neither the United Stales, nor the Commisslon, nor any person acting on behalf of the Commissions

A. Makes any warranty or representation, expressed or implied, with respect to the accuracy, com. pleteness, of usefulness of the information contained in this report, of that the use of any information, apparatus, method, or process disclosed in this report may not infringe privately owned rights, or

8. Assumes any liabilities with respect to the use of, or for domages resulting fram the use of any information, apparatus, method, or procest disclosed in this report.

As used in the above, "person acting on beholf of the Commission" includes any employee or contractor of the Commission, or employee of such sontractor, to the extent that such employee or con. tracior of the Commission, or employee of such contrector prepares, disseminates, or provides access to, any information putauant to his emplaymient of controct with the Commission, or his employment with such contractor.

\author{
PACIFIC NORTHWEST LABORATORY \\ RICHLAND, WASHINGTON \\ operated by \\ BATTELLE MEMORIAL INSTITUTE \\ for the
}

UNITED STATES ATOMIC ENERGY COMMISSION UNDER CONTRACT AT(45.1)-1830 


BNWL-174
UC-25, Metals, Ceramics,
and Materials
FIRST
UNRESTRICTED
TID-4500 4505
DISTRIBUTION
MADE

UNDERWATER REFURBISHING OF FUEL ELEMENTS

By

C. H. Allen and R. E. Sharp

Ceramics Laboratory Section

Reactor and Materials Technology Department

Dec ember, 1965

PACIFIC NORTHWEST LABORATORY

RICHLAND, WASHINGTON 
Printed in USA. Price \$1.00. Available from the Clearinghouse for Federal Scientific and Technical Information, National Bureau of Standards

U. S. Department of Commerce, Springfield, Virginia 


\section{ABSTRACT \\ UNDERWATER REFURBISHING \\ OF FUEL ELEMENTS}

Tools and procedures were developed to make underwater repairs to wire wraps and metal bands for fuel elements. Substantial cost savings have been realized, and new applications have been discovered relative to underwater removal and replacement of fuel rods in the fuel cluster and assembly and disassembly of segmented fuel rods. 


\section{TABLE OF CONTENTS}

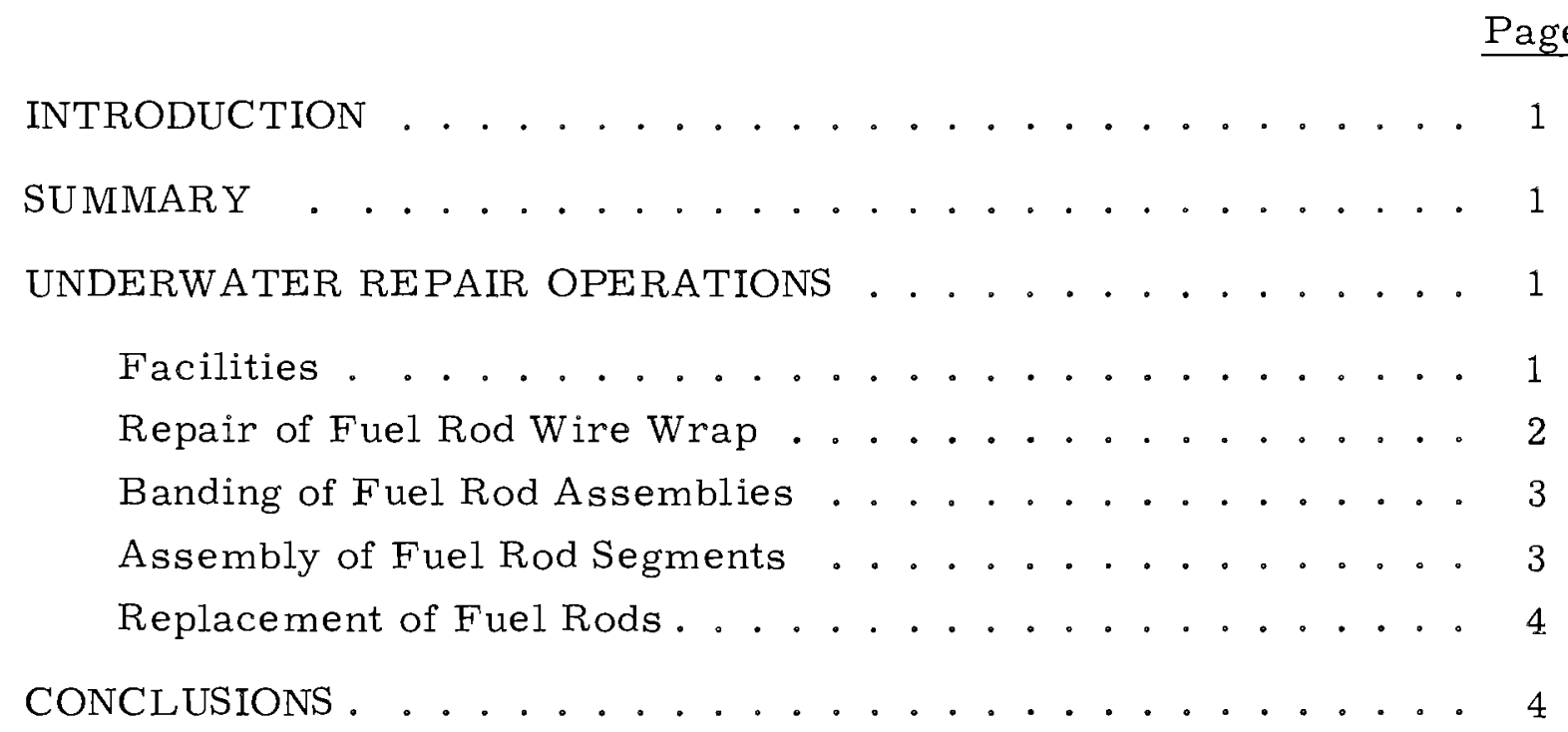





\section{UNDERWATER REFURBISHING \\ OF FUEL ELEMENTS}

\section{INTRODUCTION}

This report discusses the tools and procedures which were developed to perform underwater operations relative to the refurbishing of fuel elements, assembly of segmented fuel rods, and replacement of fuel rods. With the use of extended reach hand tools, underwater repairs were made to broken wire wraps and broken bands on Plutonium Recycle Test Reactor (PRTR) fuel rod assemblies in the reactor storage basin.

Fuel elements for the PRTR are assembled in clusters of 19 fuel rods held together by metal bands. The rods are spaced in the cluster by unbanded wire wraps which are fastened only at the rod ends. Occasionally a wire wrap will break near its termination at the end of a rod, or a band will be torn loose on the fuel element. This type of damage prevents the safe return of a fuel element to the reactor for further irradiation.

During the course of this underwater work, fuel rods were removed and replaced in the fuel cluster, and a segmented fuel rod was assembled and disassembled.

\section{SUMMARY}

Substantial cost savings have been realized by the underwater repair of damaged PRTR fuel rod assemblies. Development of extended reach hand tools has made it possible to accomplish underwater refurbishing of fuel elements in the reactor storage basin.

\section{UNDERWATER REPAIR OPERATIONS}

\section{Facilities}

The PRTR storage basin facilities were used in this project. Figure 1 shows a view of the work area. The basin is equipped with a fuel element handling tray that can move a fuel element from a vertical to a horizontal position. In the horizontal position the fuel element rests on rollers and can be rotated by turning a chuck which supports the lower end bracket of the fuel element. To optimize the working depth and to minimize 
radiation exposure to the worker, the fuel element and tray can be raised or lowered in the basin. Lighting was provided by underwater lamps, either mounted or hand held. The use of a 20 to $60 \mathrm{X}$ spotting telescope enhanced visual examination.

$\underline{\text { Repair of Fuel Rod Wire Wrap }}$

The repair of one broken wire wrap takes from 2 to $3 \mathrm{hr}$. A typical repair job is shown in Figure 2. Extended reach underwater hand tools (Figures 3 and 4) include an air-operated drill for drilling a hole in the end hanger, a special tool for holding the wire connector which permits the broken wire to be inserted into the connector, crimping pliers for crimping the ends of the wire, punches, cutting pliers, and a right angle wrench.

Wire wrap repairs are performed with the fuel element lying horizontally on the storage basin fuel handling tray 2 to $3 \mathrm{~m}$ underwater. A $6.35 \mathrm{~mm}$ diam hole is drilled through the end hanger fin closest to the broken wire on the fuel element, thus providing a means for placing a screw to clamp the wire to the fin. The loose end of the broken wire is cut back to provide a straight length of wire. A connector with a new piece of wire $10 \mathrm{~m}$ long is placed in a special holding tool (Figure 4). When the holding tool is closed around the connector, the funnel-like entrance guides the broken wire end through the connector. Pushed through the connector, the broken wire end is crimped with special pliers made from a pair of "vise grip" pliers, and the special holding tool is removed. Extended reach diagonal pliers cut off the excess wire protruding beyond the connector. The long new piece of wire is run through the end hanger, and the free end of the wire is brought above the surface of the water. Held by a pair of extended reach vise grip pliers, a screw is slid down the wire and placed in the $6.35 \mathrm{~mm}$ hole in the end hanger fin. While the screw is being held in the hole, a right angle wrench (Figure 5) is used to fit a nut on the screw. Once the nut is started, the loose end of the wire is pulled up tight, and the nut is then tightened to secure the wire. The excess wire extending beyond the screw is cut off, completing the repair. The new wire and connector are placed so that they lie between two rods. 
Banding of Fuel Rod Assemblies

Made of stainless steel, the underwater banding tool is $3.5 \mathrm{~m}_{1}$ long and can be operated by one man. It takes about 5 min to place one band. The band consists of two loops of $0.43 \mathrm{~mm}_{1}$ thick by $4.83 \mathrm{~mm}$ wide Zircaloy-2. In this procedure, the band is pulled up tight through a rack and pinion gear by the operator. After the band is tightened on the fuel element, the banding sleeve is crimped, and the extra length of banding is bent over a sharp edge on the tool and broken off. Figure 6 shows the banding tool installing a band, and Figure 7 shows the band and crimped sleeve securely holding the fuel element.

Assembly of Fuel Rod Segments

During the last several years, the Hanford Laboratories (now Pacific Northwest Laboratory) has had under development a fuel reprocessing method called the "Salt Cycle Process." Essentially, this process provides relatively simple nuclear fuel reprocessing and remote fuel element refabrication methods that could be closely integrated with a specific reactor, thus lessening the need for a large central chemical reprocessing plant. In the salt cycle process, set up on a small scale in a hot cell, the fuel, composed of $\mathrm{PuO}_{2}-\mathrm{UO}_{2}$ and some of the fission products, was electrodeposited from a molten salt solution in which the irradiated fuel was dissolved. A majority of fission products (poisons) are not deposited out of solution. Because of the radiation from the remaining fission products on the deposited fuel, new fuel elements must be fabricated, assembled, and banded in a shielded facility.

Thirty-three fuel rod segments (from salt cycle fuel), containing $2 \mathrm{wt} \% \mathrm{PuO}_{2}$, were recently fabricated remotely in a cell. Restricted to about 20 in. in length because of space limitations in the cell, these rods were vibrationally compacted, welded remotely, and transported to the PRTR storage basin. Under the water in the basin, 18 rod segments were joined to form six 60-in.-long rods. Figure 8 shows three rod segments before assembly. In this experiment, three complete rods (total of nine 
segments) were placed in an element, and then the element was banded as described earlier. All the work was performed under 2 to $3 \mathrm{~m}$ of water, with no difficulties. The bottom segment was placed in the fixture shown in Figure 9. With a slot fitting the hex on the segment end caps, this fixture keeps the rod from turning when the next segment is screwed into place. When the first segment is placed in the fixture, a Zircaloy-2 sleeve is attached to the cap and the next segment is gripped (on the end cap hex) in a special wrench and screwed into place (Figure 10). The wrench is then released and removed, and two joined segments are lifted out of the fixture and dropped down. The third segment is screwed into position in the same manner, completing the assembly. The completed fuel rod is then laid into an open position in a fuel bundle and held in place by a screw inserted through the top end hanger and screwed into the end cap on the top fuel rod segment. These steps are depicted in Figures 11 and 12 .

Replacement of Fuel Rods

Three experimental fuel elements were irradiated in the PRTR. After some irradiation, three fuel rods were removed (on separate occasions, two in one instance and one in the other) and replaced with new rods. Using tools shown in Figure 4, these rods were replaced under about 2 to $3 \mathrm{~m}$ of water in the reactor storage basin.

\section{CONCLUSIONS}

The underwater fuel element refurbishing program has resulted in cost savings of $\$ 3,000$ to $\$ 5,000$ for each damaged PRTR fuel element that has been salvaged. Developed to effect the underwater repairs of damaged fuel rod assemblies, the relatively simple extended reach hand tools used in this work might be effectively employed in a proposed fuel re-use program, (1) wherein blanket fuel from a fast reactor is assembled into fuel elements for thermal reactor use. The assembly and disassembly of segmented rods could be a simple way of doing this job.

1. R. J. Hennig, P. L. Hofman, and G. J. Busselman. Fuel Re-use Analysis of a Fast Thermal Reactor Complex, HW-74549, General Electric, Richland, Washington. September 24, 1962. 


\section{ACKNOWLEDGEMENT}

The author appreciates the excellent work Roy Sharp performed on the design of the extended reach band tools. 


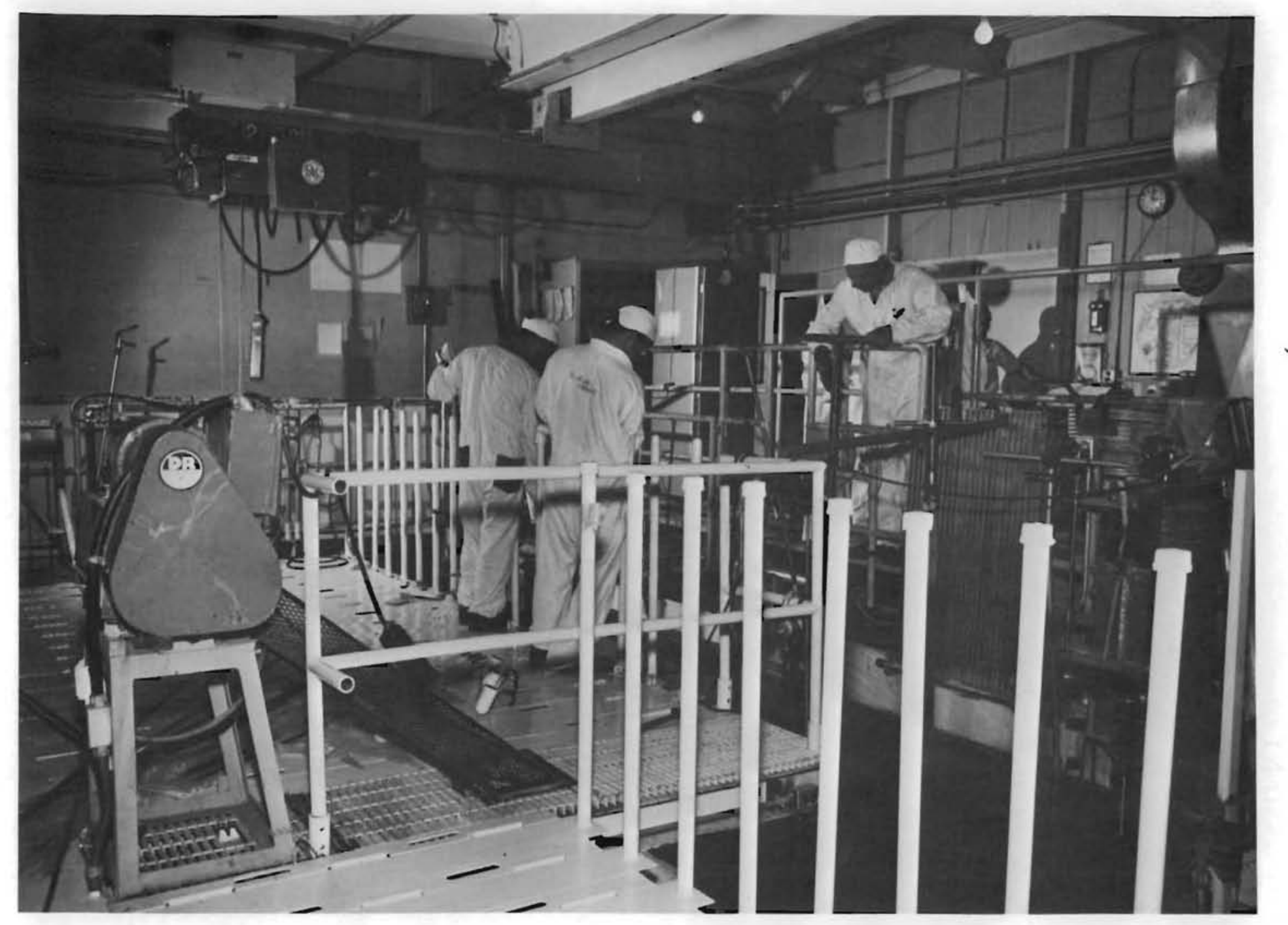

FIGURE 1

PRTR Storage Basin Work Area 


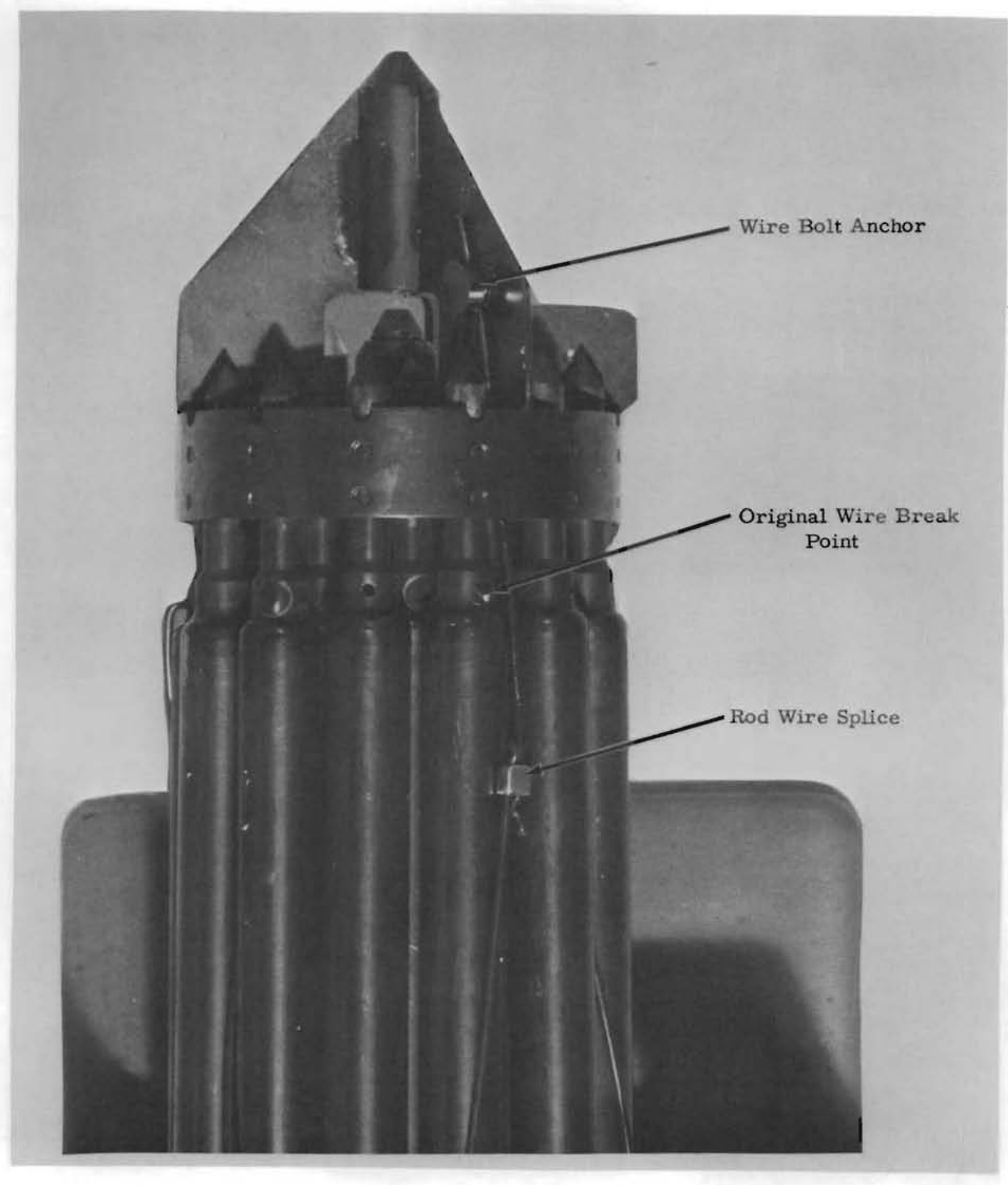

FIGURE 2

Fuel Rod Assembly with Repaired Wire Wraps 


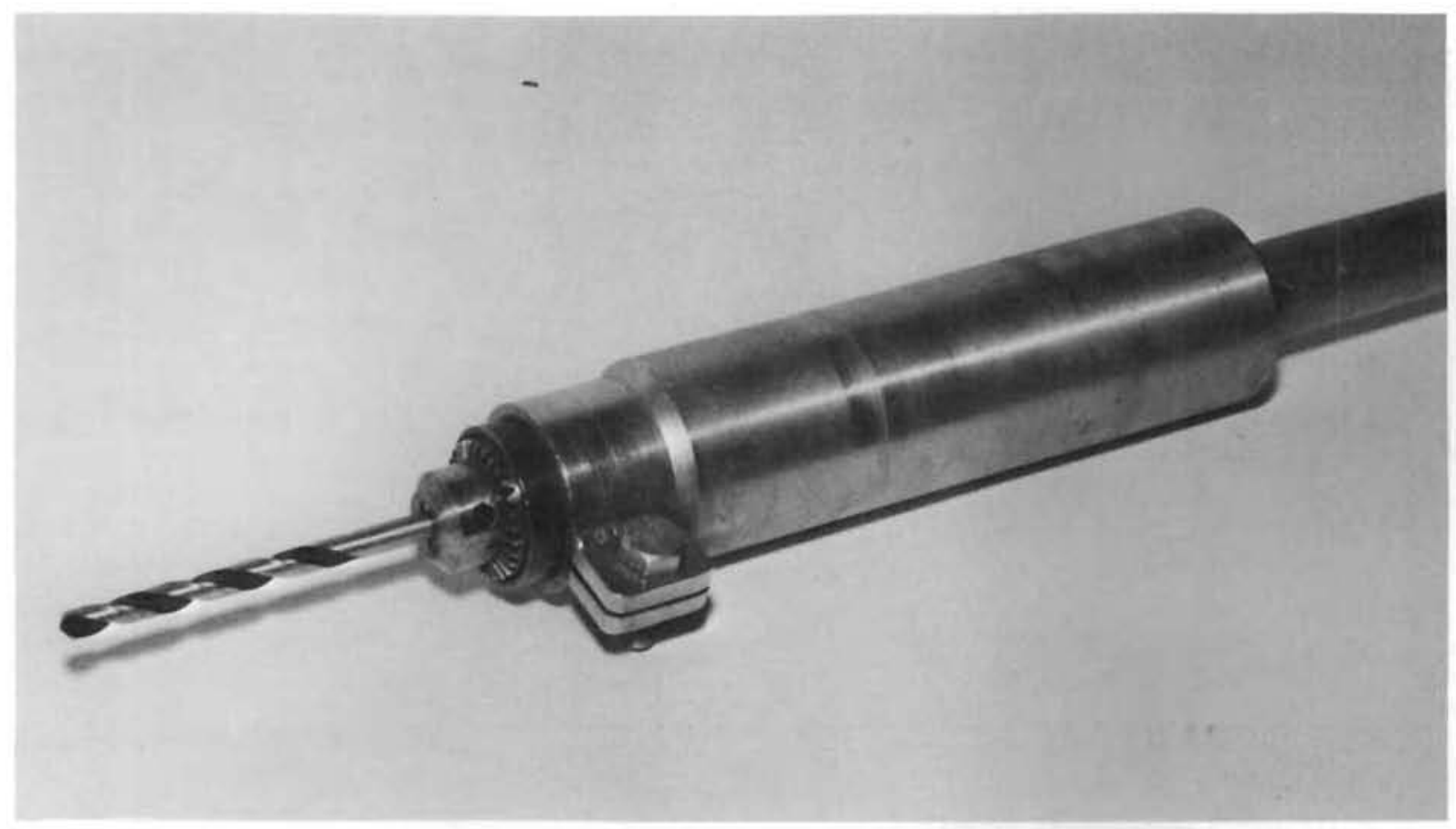

FIGURE 3

Underwater Air-Operated Drill Motor and Drill

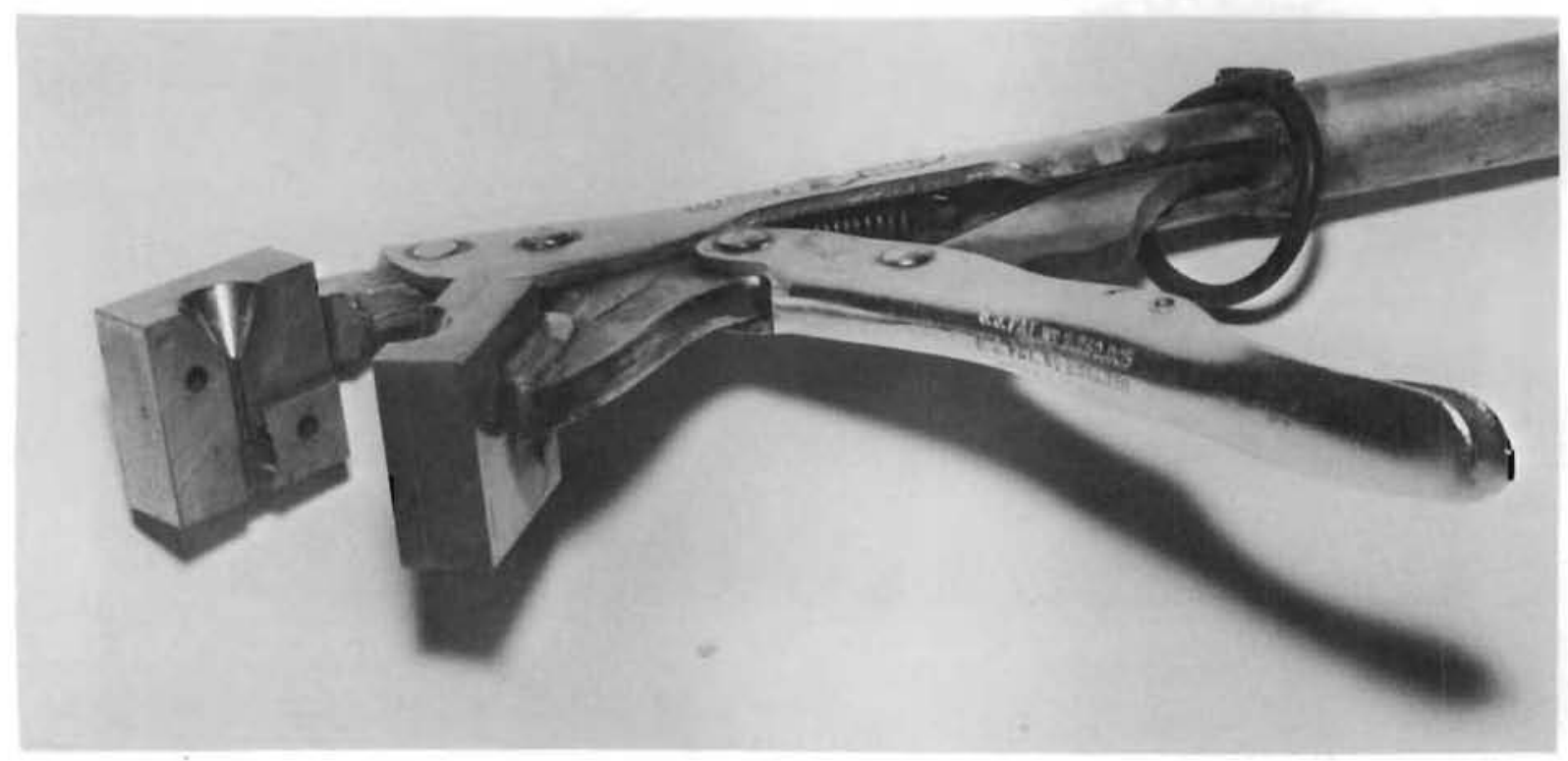

FIGURE 4

Wire Connector Holding Tool 


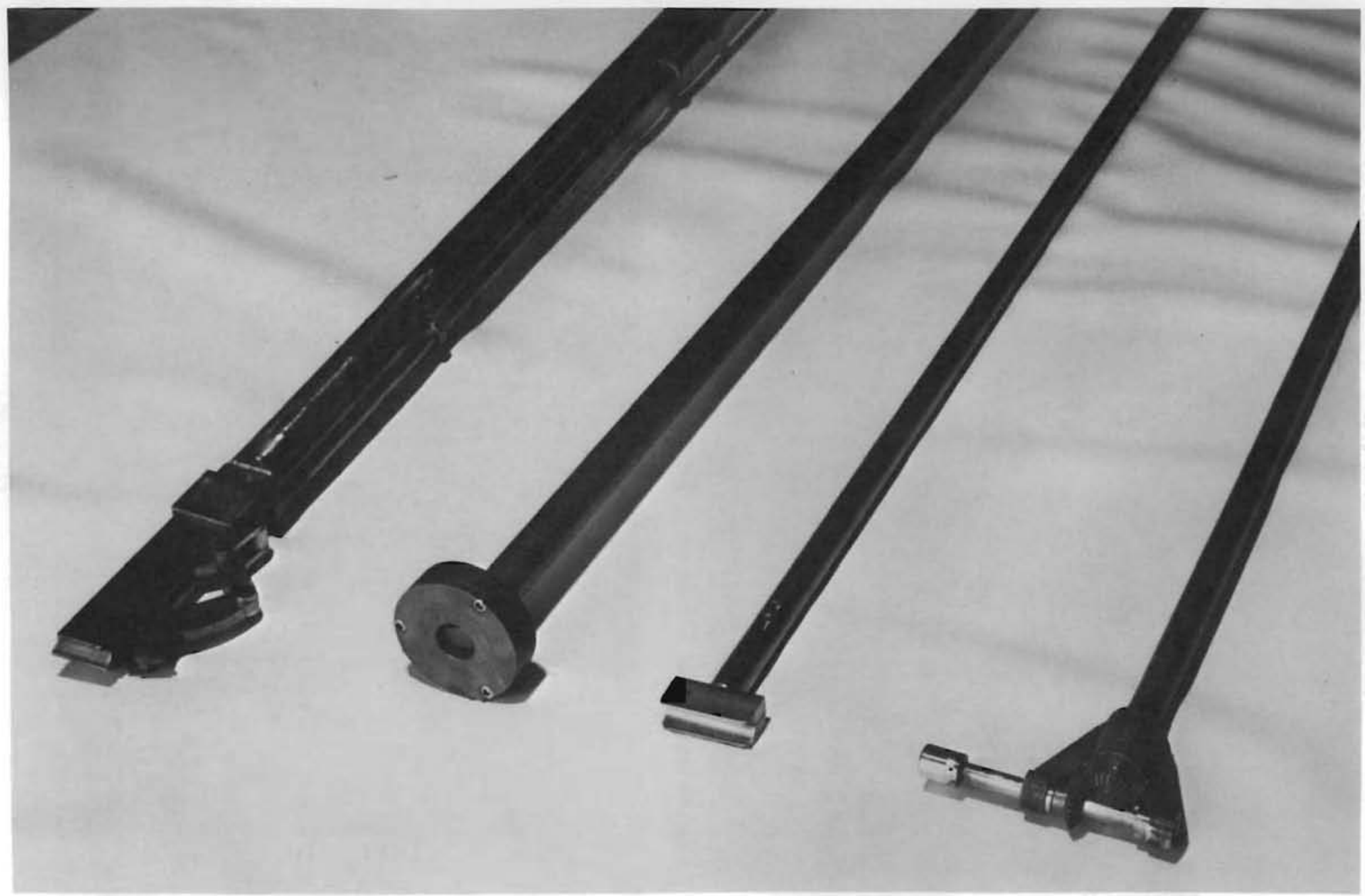

6

FIGURE 5

Bonding Tool, Rod Wrench,

Rod Bonding Tool, and Right Angle Wrench, 


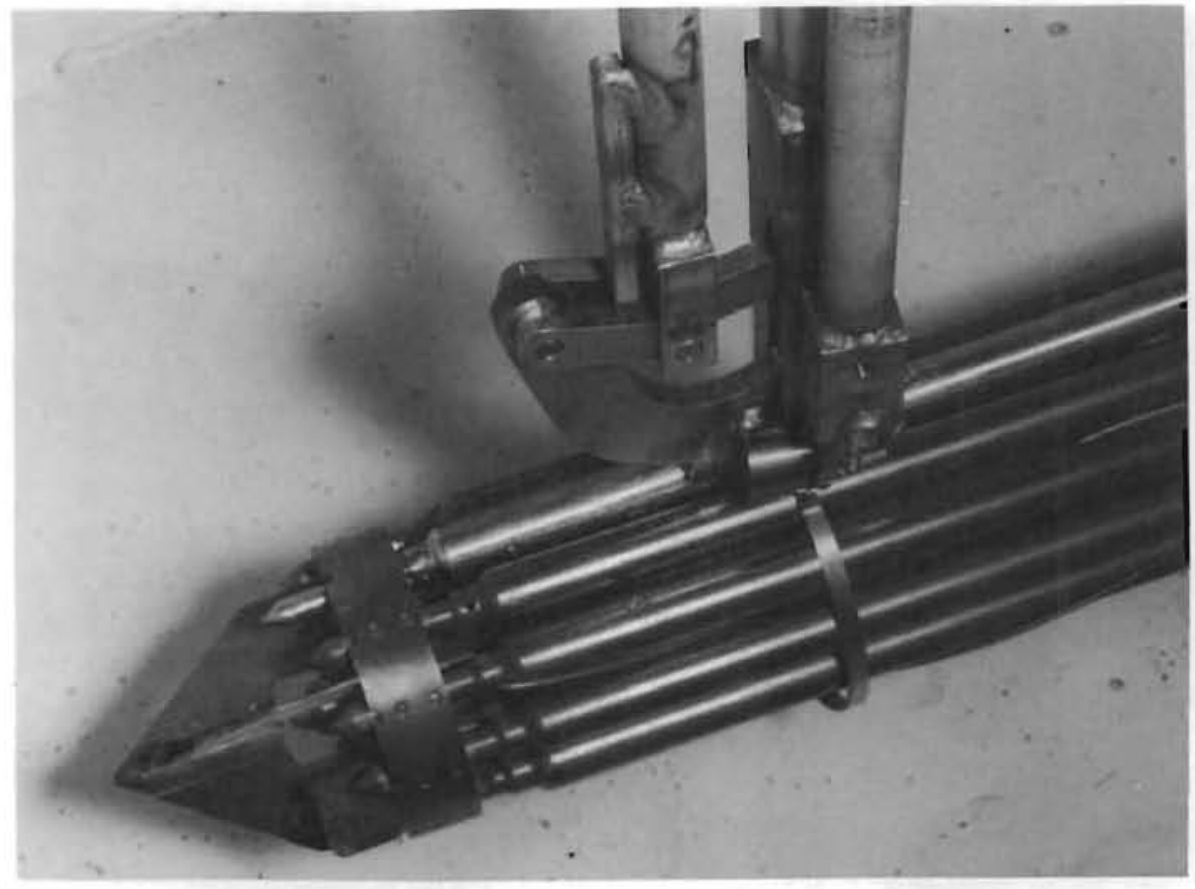

FIGURE 6

Installation of Band on a Fuel Rod Assembly

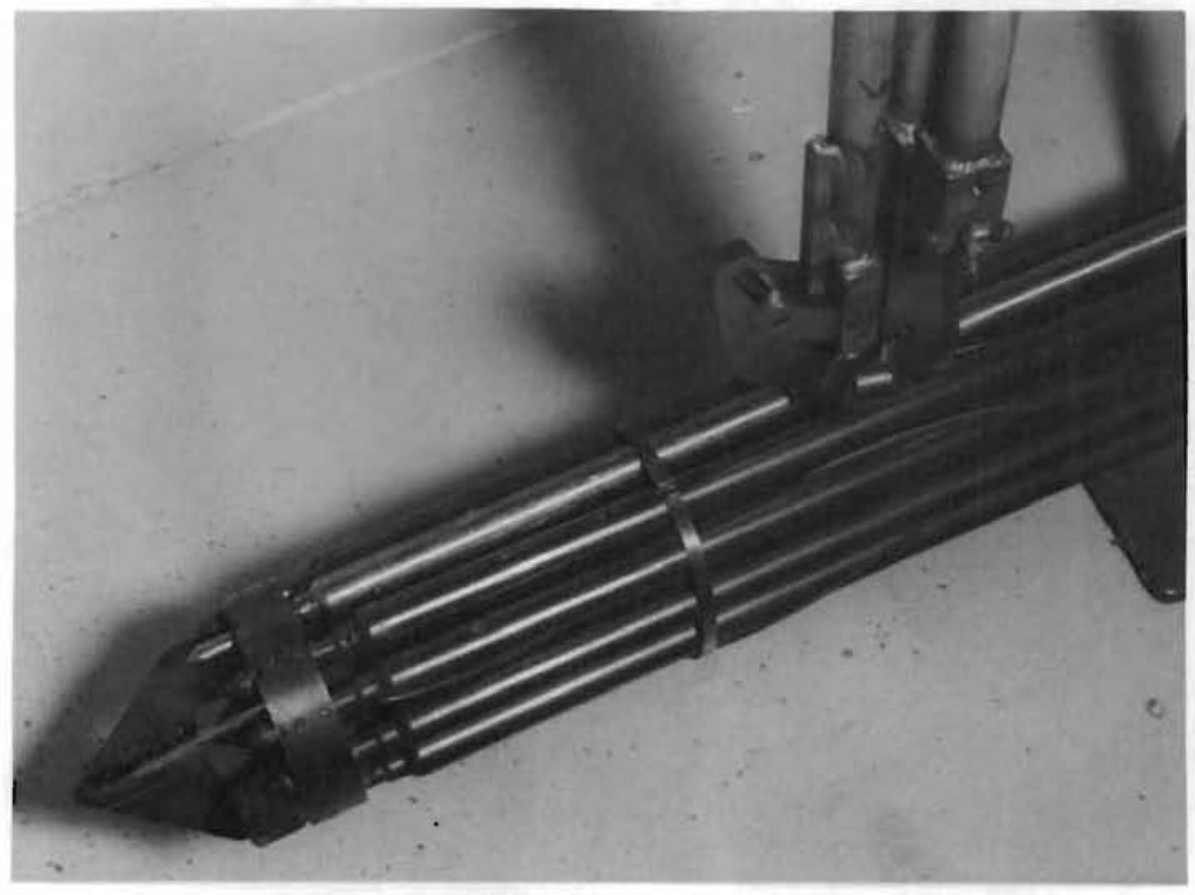

FIGURE 7

Fuel Rod Assembly with Band in Place 


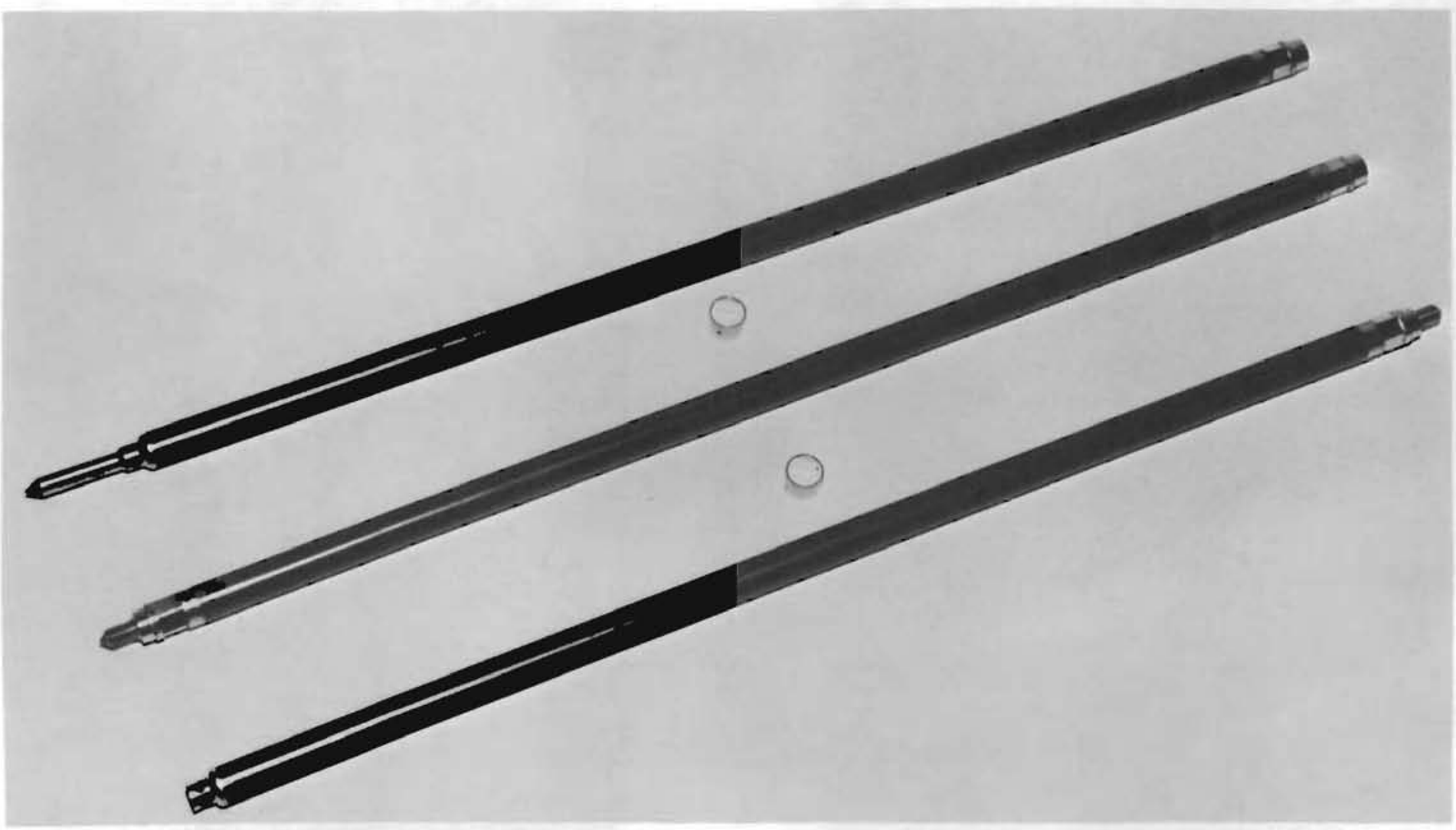

FIGURE 8

Fuel Rod Segments 


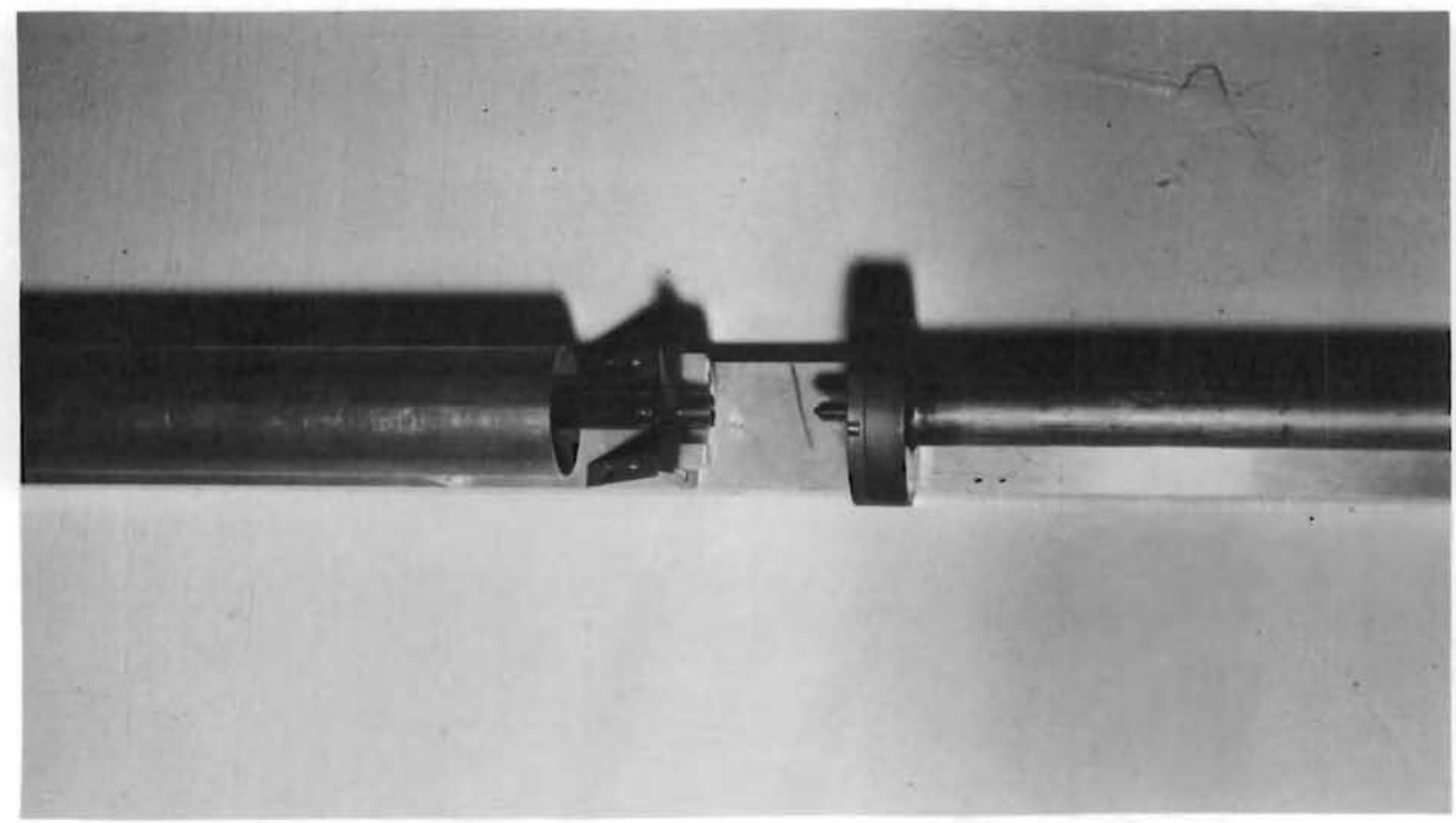

\section{FIGURE 9}

Assembly Fixture and Rod Segments

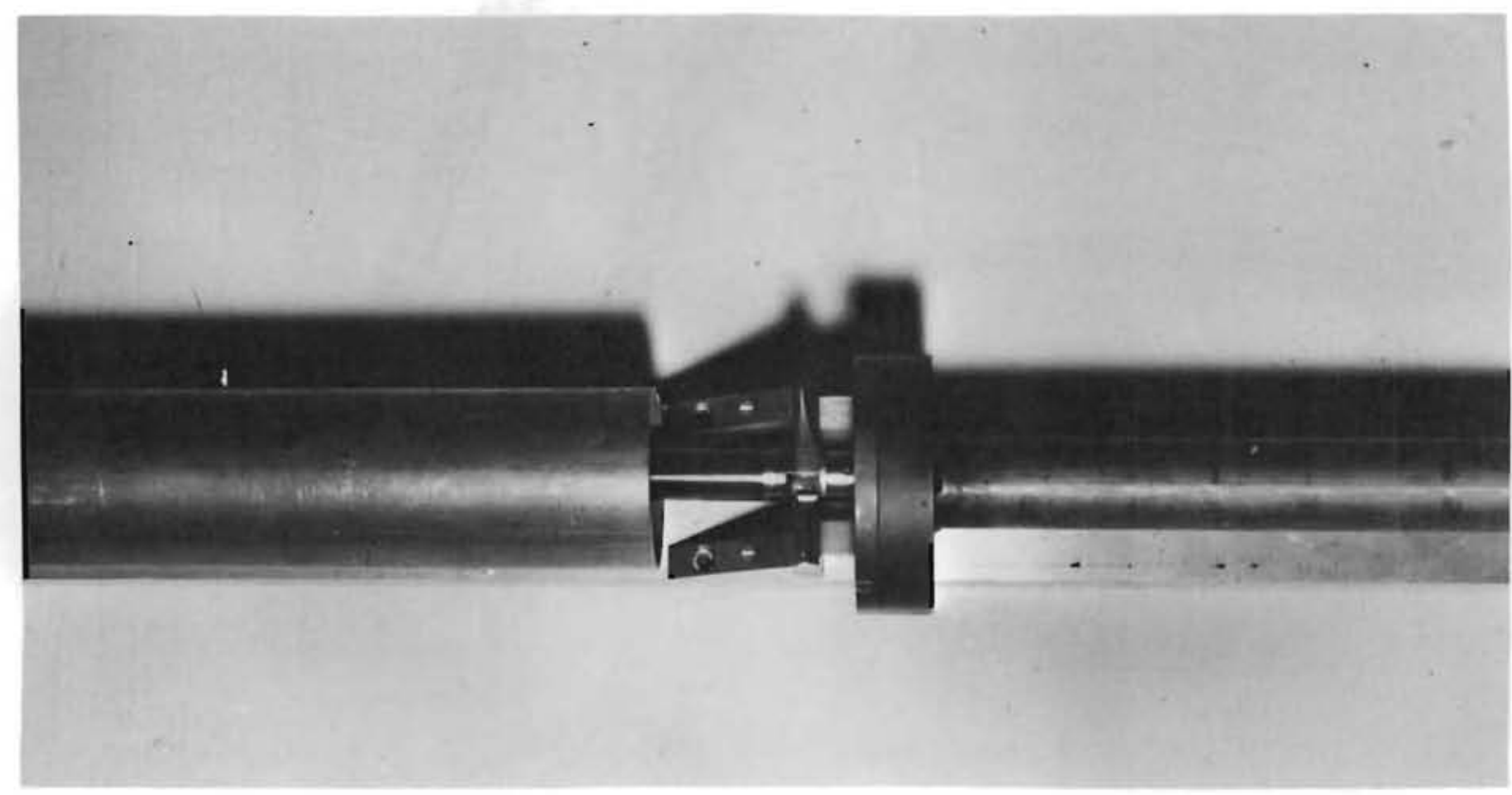

FIGURE 10

Assembly of Rod Segments 


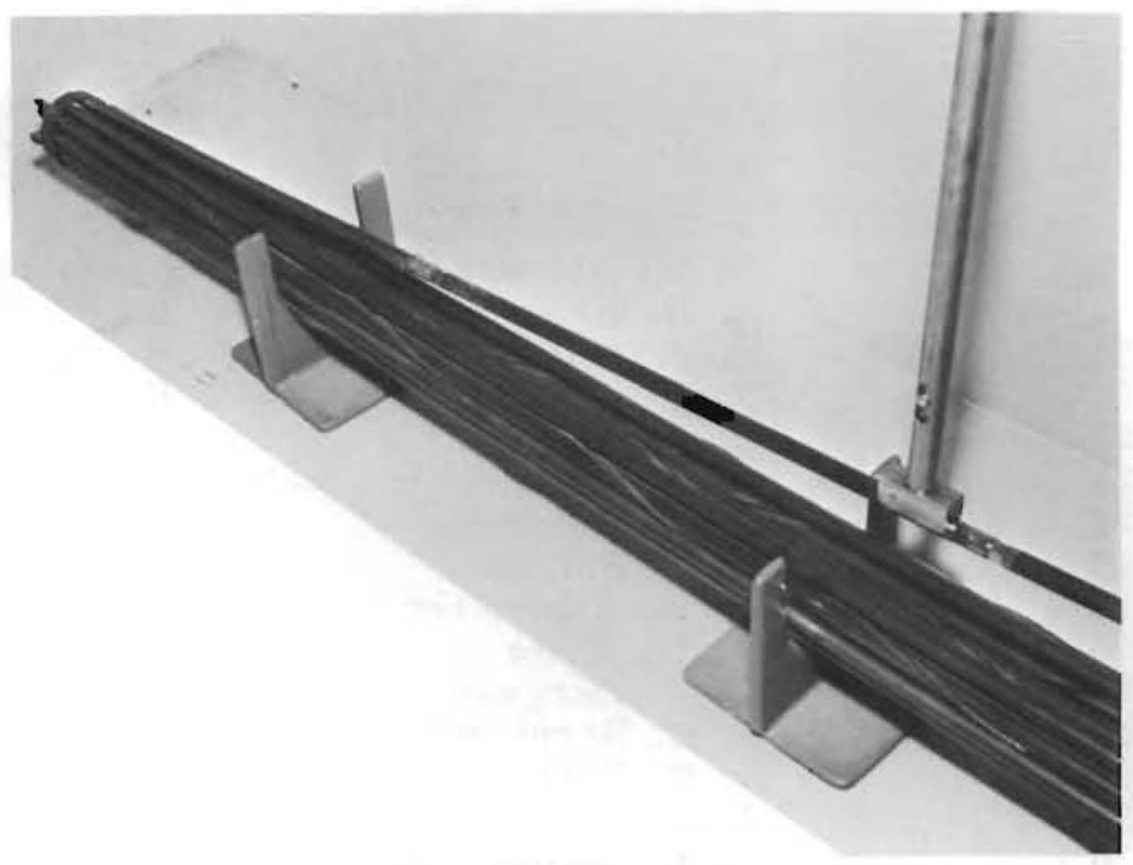

FIGURE 11

Placing Segmented Fuel Rod in Fuel Rod Cluster

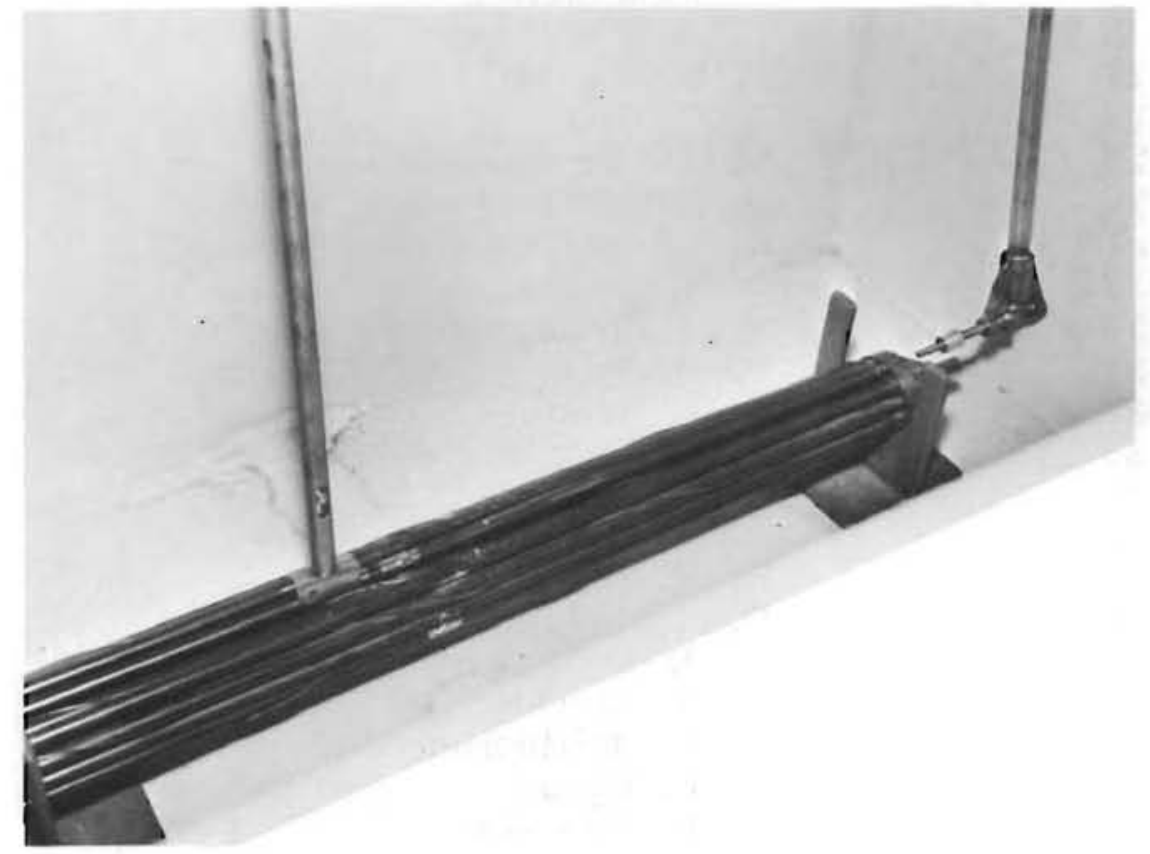

FIGURE 12

Inserting Screw in End Hanger and Cap 


\section{ONSITE DISTRIBUTION}

Copy Number

Pacific Northwest Laboratory

\begin{tabular}{|c|c|c|c|}
\hline 1 & F. W. Albaugh & 50 & R. E. Sharp \\
\hline $2-7$ & C. H. Allen & 51 & R. R. Sharp \\
\hline 8 & H. J. Anderson & 52 & R. E. Skavdahl \\
\hline 9 & R. J. Anicetti & 53 & R. C. Smith \\
\hline 10 & E. R. Astely & 54 & R. D. Widrig \\
\hline 11 & W. J. Bailey & 55 & F. W. Woodfield \\
\hline 12 & R. E. Bardsley & 56 & Technical Publications, \\
\hline 13 & E. J. Barrett & & 300 Area \\
\hline 14 & C. H. Bloomster & 57 & Technical Publications, \\
\hline 15 & D. W. Brite & & 700 Area \\
\hline 16 & C. A. Burgess & 58 & Technical Information \\
\hline 17 & J. B. Burnham & & Files \\
\hline 18 & S. H. Bush & & \\
\hline 19 & J. J. Cadwell & & \\
\hline 20 & G. W. Dalen & & \\
\hline 21 & F. G. Dawson, Jr. & & \\
\hline 22 & D. R. de Halas & & \\
\hline 23 & D. E. DeWitt & & \\
\hline 24 & R. F. Dickerson & & \\
\hline 25 & K. Drumheller & & \\
\hline 26 & E. A. Eschbach & & \\
\hline 27 & S. L. Fawcett & & \\
\hline 28 & J. C. Fox & & \\
\hline 29 & M. D. Freshley & & \\
\hline 30 & S. Goldsmith & & \\
\hline 31 & R. L. Gulley & & \\
\hline 32 & J. R. Hague & & \\
\hline 33 & W. L. Hampson, Jr. & & \\
\hline 34 & H. Harty & & \\
\hline 35 & J. J. Hauth & & \\
\hline 36 & R. J. Hennig & & \\
\hline 37 & G. R. Horn & & \\
\hline 38 & J. R. Keenan & & \\
\hline 39 & R. F. Klein & & \\
\hline 40 & D. C. Lehfeldt & & \\
\hline 41 & R. J. Lobsinger & & \\
\hline 42 & L. G. Merker & & \\
\hline 43 & M. K Millhollen & & \\
\hline 44 & R. E. Olson & & \\
\hline 45 & F. E. Paniska & & \\
\hline 46 & H. M. Parker & & \\
\hline 47 & L. A. Pember & & \\
\hline 48 & W. D. Richmond & & \\
\hline 49 & W. E. Roake & & \\
\hline
\end{tabular}


ONSITE DISTRIBUTION (contd)

Copy Number

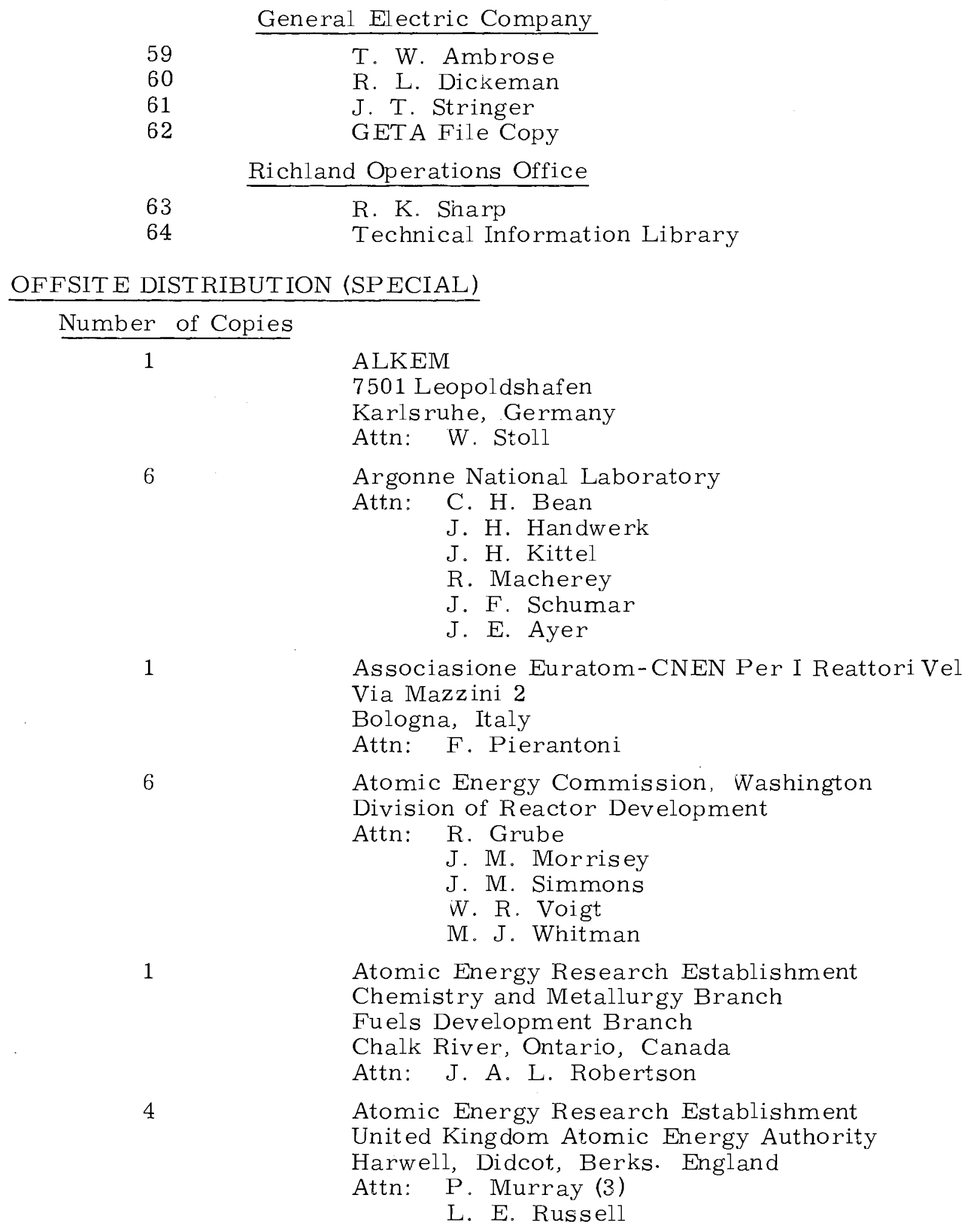


OFFSITE DISTRIBUTION (SPECIAL) (contd)

Number of Copies

1

2

4

1

1

1

3

3

5

1

1
Atomics International

Attn: B. R. Hayward

Atomic Power Development Associates

119 First Street

Detroit 26, Michigan

Attn: W. H. Jens

A. A. Shoudy

Battelle Memorial Institute

Attn: D. L. Keller

S. W. Porembka (2)

W. F. Heenan

Centre d'Etudes Nucleaires de Cadarache Boite Postale No. 1

Saint-Paul-Lez-Durance, France

Attn: Dr. B. DeFreyn

Combustion Engineering, Inc.

Attn: J. C. Tobin

European Atomic Energy Community

51-53 Rue Belliard (Euratom)

Brussels 4, Belgium

Attn: Pierre Kruys

General Electric Company, Cincinnati

Attn: E. A. Aitken

W. Briskin

J. McGurty

General Electric Company, Pleasanton

Attn: L. P. Bupp

E. A. Evans

A. I. Kaznoff

General Electric Company, San Jose

Attn: K. Cohen

A. N. Holden

T. J. Pashos

B. Weidenbaum

E. L. Zebroski

Kerr-McGee Industry Inc.

Oklahoma City, Oklahoma

Attn: Harold Lambertus

Knolls Atomic Power Laboratory

Attn: W. K. Barney 


\section{OFFSITE DISTRIBUTION (SPECIAL) (contd)}

Number of Copies

5

2

1

4

1

1

1

3

2

4

1
Los Alamos Scientific Laboratory

Attn: R. Baker

M. Bowman

H. Hessing

D. MacMillan

R. Spence

NASA Lewis Research Center

Attn: A. F. Lietzke

N. T. Saunders

Transuranium Institute (Euratom)

Karlsstrasse 42-44

Karlsruhe, Germany

Attn: H. M. Mattys

Union Carbide Corporation (ORNL)

Attn: R. M. Carroll

J. L. Scott

W. C. Connally

United Aircraft Corporation

Research Laboratory

East Hartford, Connecticut

Attn: G. H. McLafferty

University of Arizona

Nuclear Engineering Department

Tucson, Arizona

Attn: Monte V. Davis

University of Michigan

College of Engineering

Ann Arbor, Michigan

Attn: $W$. Kerr

U. S. Atomic Energy Commission

Brussels, Belgium

Attn: C. F. Schank

Westinghouse Bettis Atomic Power Laboratory

Attn: J. Belle

B. Lustman

Westinghouse Electric Corporation

Attn: Robert Allio

A. A. Bishop

A. Boltax

N. R. Nelson

Wright Air Development Center

AF Materials Laboratory

Wright Patterson AFB, Dayton, Ohio

Attn: S. W. Bradstreet 


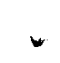

